\title{
Manajemen Pembelajaran Nahwu Shorof di Pondok Pesantren Apik Kesugihan Ulfatul Khasanah
}

(MI Nurul Huda Karangkandri)

oelfachoesna@gmail.com

\begin{abstract}
APIK Islamic boarding schools in learning management must refer to general managerial patterns that begin with planning and end with evaluation, while salafiyyah Islamic boarding schools which are mono managerial in all respects include their nahwu shorof learning which makes learning books in Islamic boarding schools only take place naturally. Nahwu shorof learning management applied in PP. APIK which in fact is a boarding school that still maintains the salafiyyah tradition and has not systematically implemented the nahwu shorof learning management pattern in detail. The purpose of this study was to determine the natural background of PP. APIK, planning, organizing, implementing and evaluating nahwu shorof learning. The theory used in this study is learning management according to H.E. Mulyasa in a paper entitled MPDI curriculum development according to KKNI and SNPT 27/11/2015 states that micro-management of learning includes planning, implementation and evaluation. The method used in this research is qualitative with a case study approach. Data collection techniques include observation, interviews and documentation studies. The results of this study concluded that the learning management of Nahwu Shorof at APIK Islamic boarding schools can be described from planning, implementation and evaluation. Learning planning at the APIK Islamic boarding school is based on the ability of the students themselves, if the students are still unfamiliar with their Islamic boarding school's knowledge in learning books, then it is adjusted to be oriented towards studying books that are basic to the highest. The implementation of nahwu shorof learning at the APIK Islamic boarding school is divided into two classical systems, namely ibtida/tsanawi. The evaluation of nahwu shorof learning at the APIK Islamic boarding school is oriented towards the completeness of the material, one book is studied continuously and repeatedly until in the end the students understand the contents of the book they are studying with the sorogan, bandungan and rote systems.
\end{abstract}

Keywords: Management, Learning, Nahwu Shorof, Islamic Boarding School 


\begin{abstract}
Abstrak
Pondok pesantren APIK dalam manajemen pembelajaran haruslah mengacu pada pola manajerial umum yang diawali dengan perencanaan dan diakhiri evaluasi, sedangkan pondok pesantren salafiyyah yang bercorak mono manajerial dalam segala hal nyatermasuk dalam pembelajaran nahwu shorofnya yang menjadikan pembelajaran kitab di pondok pesantren hanya berlangsung alamiah. Manajemen pembelajaran nahwu shorof yang diterapkan di PP. APIK yang pada faktanya adalah pondok pesantren yang masih menjaga tradisi salafiyyah serta belum secara detail menerapkan pola manajemen pembelajaran nahwu shorof dengan sistematis. Tujuan penelitian ini adalah untuk mengetahui latar alamiah PP. APIK, perencanaan, pengorganisasian, pelaksanaan dan evaluasi pembelajaran nahwu shorof. Teori yang digunakan dalam penelitian ini adalah manajemen pembelajaran menurut H.E. Mulyasa dalam makalah berjudul pengembangan kurikulum MPDI sesuai KKNI dan SNPT 27/11/2015 menyatakan bahwa manajemen pembelajaran secara mikro meliputi perencanaan, pelaksanaan dan evaluasi. Metode yang digunakan dalam penelitian ini adalah kualitatif dengan pendekatan studi kasus. Teknik pengumpulan data diantaranya observasi, wawancara dan studi dokumentasi. Hasil penelitian ini diperoleh kesimpulan bahwa, manajemen pembelajaran Nahwu Shorof di pondok pesantren APIK dapat diuraikan dari perencanaan, pelaksanaan dan evaluasi. Perencanaan pembelajaran di pondok APIK pada kemampuan santrinya itu sendiri, jika santri tersebut masih awam keilmuan pesantrennya dalam pembelajaran kitab maka disesuaikan dengan diorientasikan mempelajari kitab-kitab yang mendasar hingga yang tertinggi. Pelaksanaan pembelajaran nahwu shorof di pondok pesantren APIK dibagi menjadi dua sistem klasikal yaitu ibtida/tsanawi. Evaluasi pembelajaran nahwu shorof di pondok pesantren APIK berorientasi pada ketuntasan materi, satu kitab dipelajari secara terus menerus dan berulang-ulang hingga pada akhirnya santri memahami isi dan kandungan dari kitab yang dipelajarinya tersebut dengan sistem sorogan, bandungan dan hafalan.
\end{abstract}

Kata Kunci: Manajemen, Pembelajaran, Nahwu Shorof, Pesantren

\title{
PENDAHULUAN
}

Pondok Pesantren APIK adalah singkatan dari Asrama Pelajar Islam Kesugihan atau biasa disebut dengan PonPes APIK Kesugihan yaitu merupakan Pondok Pesantren yang berada di wilayah Kesugihan, tepatnya berada di Jalan Kebon Salak Rt. 02 Rw. 06 Kecamatan Kesugihan Kabupaten Cilacap.

Pondok Pesantren APIK merupakan lembaga pendidikan non formal yang di dalamnya terdapat pengasuh santri (kyai), ustadz dan ustadzah, santriwan dan santriwati, serta asrama untuk menginap (pondok) serta aula (mushola) untuk mengaji para santri. Jika Menurut Nurcholis Madjid dalam Panduan Integrasi Kultur Pesantren ke dalamManajemen Sekolah bahwasannya pesantren adalah lembaga pendidikan yang paling besarkontribusinya terhadap penyelamatan pengangguran. ${ }^{1}$ Pondok Pesantren APIK Kesugihan ini merupakan Pondok Pesantren salaf yang lebih menekankan dan

\footnotetext{
${ }^{1}$ Kementerian Agama RI, Panduan Integrasi Kultur Kepesantrenan ke dalam Manajemen Sekolah (KemenagRI: 2012), hlm. 7.
} 
memperdalam pembelajaran kitab-kitab Nahwu, Shorof, Akhlaq, Tajwid, Hadits, Tauhid, Fiqih dan lain-lain. Adapun visi dari Pondok Pesantren APIK itu sendiri yaitu "Mencetak santri yang berakidah dan berakhlakul karimah" sebagai figur yang dapat dijadikan teladan bagi umat. sedangkan misinya yaitu "Mewujudkan insan kamil, cakap serta berwawasan ilmu pengetahuan".

Pondok Pesantren APIK Kesugihan ini merupakan Pondok Pesantren salaf yang lebih menekankan dan memperdalam pembelajaran kitab-kitab Nahwu, Shorof, Akhlaq, Tajwid, Hadits, Tauhid, Fiqih dan lain-lain. Adapun visi dari Pondok Pesantren APIK itu sendiri yaitu "Mencetak santri yang berakidah dan berakhlakul karimah" sebagai figur yang dapat dijadikan teladan bagi umat. sedangkan misinya yaitu "Mewujudkan insan kamil, cakap serta berwawasan ilmu pengetahuan".

Pesantren merupakan bagian dari pendidikan Islam di Indonesia, didirikan karena adanya tuntutan dan kebutuhan zaman. Hal ini bisa dilihat dalam perjalanan sejarah, "Bila dirunut kembali, sesungguhnya pesantren dilahirkan atas kesadaran dan kewajiban dakwah Islamiyah, sekaligus mencetak kader-kader ulama dan da ${ }^{\text {ee }}$. Lembaga pesantren muncul sebagai harapan bangsa Indonesia, yang sudah umum diselenggarakan". Kelebihan sistempesantren dibanding dengan sekolah biasa yang tanpa asrama ialah bahwa peserta didik berada dalam lingkungan suasana pendidikan selama 24 jam, dan para pendidik atau pengasuh dapat mengawasi, membimbing, dan memberi teladan kepada mereka secara total. "Ini akan memudahkan usaha pencapaian tujuan-tujuan pendidikan, sehingga hasilnya dapat berlipat ganda dari hasil pendidikan sekolah biasa. Peserta didik di lembaga pendidikan pesantren diarahkan membiasakan diri untuk mengamalkan ajaran Islam". Seperti dalam melaksanakan shalat, berpakaian, makan, minum, sopan-santun dan lain sebagainya. Dalam soal ibadah bukan hanya yang bersifat wajib yang harus dikerjakan namun juga ibadah yang bersifat anjuran. Pembiasaan ini dilakukan agar peserta didik terbiasa mengamalkan ajaran Islam. Seperti shalat malam (shalat tahajud), shalatdhuha, puasa Senin dan Kamis. "Era globalisasi dewasa ini dan di masa datang sedang dan akan mempengaruhi perkembangan sosial budaya masyarakat muslim Indonesia umumnya, atau pendidikan Islam, termasuk pesantren khususnya”.

Di era globalisasi yang semakin berkembang seperti sekarang ini, pendidikan, baik pendidikan formal maupun non formal (Pesantren dan Madrasah Diniyah/Madin) 
mempunyai peran yang sangat penting dalam kehidupan manusia. Pendidikan bertujuan untuk membentuk karakter suatu bangsa serta mencerdaskan kehidupan bangsa agar bangkit dari sebuah kebodohan dan keterpurukan. Untuk mencapai pendidikan tersebut diperlukanmanajemen yang baik. Manajemen pendidikan yang sudah tertata dengan baik akanmenghasilkan output yang berkualitas juga. Untuk itu dibutuhkan dukkungan dari sumberdaya manusia yang profesional, tenaga pendidik dan kependidikanyang berkompetensi, sarana dan prasarana yang mendukung serta memadai untuk jalannya proses belajar mengajar di Pondok, anggaran yang cukup serta dukungan dari masyarakat sekitar serta dukungan dari pemerintah. Selain itu juga diperlukan evaluasi yang bertujuan untuk mengetahui sejauh mana tercapainya tujuan pendidikan non formal yang ada di Pondok Pesantren APIK. Apakah sudah sesuai dengan tujuan yang kita harapkan.

Pondok pesantren APIK adalah sebuah lembaga pendidikan non formal yang berada di Kecamatan Kesugihan Kabupaten Cilacap dimana para santri tinggal di asrama itu dengan mengkaji materi pengajaran kitab-kitab kuning atau klasik dan kitab-kitab lain. Yang tujuannya untuk menguasai ilmu agama Islam secara detail, terutama kitab nahwu shorofnya, serta mengamalkannya sebagai pedoman hidup keseharian dengan menekankan pentingnya moral dalam kehidupan bermasyarakat.

Pondok pesantren menjadi sebuah institusi swasta yang bergelut di bidang pendidikan agama dan memiliki kekhususan dalam kegiatan pembelajarannya yang menjadikan pembeda antara pendidikan pesantren dengan isntitusi pendidikan lainnya, dan juga orientasi pendidikan di pondok pesantren lebih diperioritaskan pada urusan agama dan akhirat, sehingga pembelajarannya terasa sakral dan khidmat. Di dunia pesantren ilmu-ilmu agama diajarkan oleh para ustadz dan ustadzah bahkan kyai sebagai penggerak dalam perkembangan para santrinya. Pesantren memiliki peran yang tidak dapat diragukan lagi sebagai lembagapusat penyaluran ilmu-ilmu keislaman yang di dalamnya banyak diajarkan nilai-nilai keislaman sebagai sarana dan tempat mencetak para pakar agama dan pewaris Nabi untuk menghilangkan kebodohan dikalangan masyarakat.

Namun sangat disayangkan dalam realitanya pembelajaran kitab Nahwu Shorof selama ini yang terjadi, masih banyaknya ditemukan yang belum mencapai kapasitas yang setara antara keahlian berbahasa dengan kemampuan metodologis 
pembelajaran Nahwu Shorof, sehingga tidak mampu mengajarkan materi dengan cakap. Pengajar Nahwu Shorof yang kurang cakap dalam mengajarnya akan menyebabkan kurang optimalnya dalam memenuhi kebutuhan peserta didiknya. Kenyataan ini banyak membawa konsekuensi yang serius sehingga banyak kegagalan dalam pembelajaran Nahwu Shorof dan banyak dari siswa yang belum bisa membaca kitab kuning hal ini akan mempengaruhi dalam proses maupun hasil pembelajaran itu sendiri yang pada akhirnya akan suilt untuk dipahami oleh santri. Semuanya menandakan akan pentingnya sebuah cara ataupun metode pembelajaran karena keberhasilan para santri dalam pembelajaran kitab Nahwu Shorof tergantung kecermatan dalam memilih metode untuk diterapkan dalam penyampaian materi.

Hal tersebut merupakan problematika yang melanda dunia pendidikan pesantren, namun juga banyak pondok pesantren yang cerdas dalam memilah metode-metode pembelajaran Nahwu Shorof. Mereka mengkolaborasikan metode klasik dengan metode pembelajaran yang modern, bahkan dengan pembelajaran model tersebut menjadikan parasantrinya mudah dalam memahami pembelajaran yang sebelumnya cukup merumitkan para santrinya sehingga hal ini akan memudahkan mereka dalam mempelajari kitab-kitab para ulama baik yang klasik maupun kontemporer sebagai bekal pengetahuan dan wawasan akan ajaran agama yang dalam sehingga meningkatkan religiusitas santri yang mempelajarinya.Seperti di salah satu pondok pesantren yang peneliti jadikan sebagai objek penelitian yakni Pondok Pesantren APIK Kesugihan.

Selama ini, kontribusinya dalam rangka mencerdaskan kehidupan bangsa sekaligus mencetak kader-kader intelektual yang siap untuk mengapresiasikan potensi keilmuannya di masyarakat tidak dapat diragukan lagi. Hal ini sejalan dengan tujuan pendidikan universal yang (berusaha) menciptakan keseimbangan pertumbuhan kepribadian manusia secara menyeluruh dengan cara melatih jiwa, akal pikiran, perasaan dan fisik manusia. Sehingga yang dilahirkan pesantren bukan hanya orang yang siap secara rohani dan fisik saja, tapi juga secara mental. Maka 
sejarah mencatatbagaimana perjuangan santri melakukanpemberontakan (santri insurrection) untuk melawan imprealis Belanda pada abad ke $19{ }^{2}$

Bukti dari eksistensi Pondok Pesantren dalam kanca pendidikan Nasional begitu menggema adalah dengan bertambahnya jumlah pesantren di Indonesia dari Tahun ke tahun. Menurut data, pada tahun 1997-1998, jumlah pesantren hanya 9.388 dengan jumlah santri. 1.770.768, maka sepuluh tahun kemudian, tepatnya tahun 2007-2008, jumlahnya meningkat menjadi 17.506 dengan jumlah santri 3.289. 141 dan tiga tahun kemudian (2010-2011) meningkat lagi menjadi 27. 218 dengan jumlah santri sebanyak 3.648.738. ${ }^{3} 3$ jumlah tersebut akan terus bertambah dari tahun ke tahun, mengingat mulai beragamnya pendidikan yang dikelola oleh pesantren, mulai dari TK sampai Perguruan Tinggi. Banyaknya kuantitas tersebut, sangat strategis dan menguntungkan bagi pembangunan bangsa Indonesia. Dengan catatan, seluruh potensi yang dimiliki pesantren dapat diberdayakan secara maksimal.

Keberhasilan pesantren untuk terus survive bahkan berkembang menjadi lebih maju seperti itu dicatat oleh Azyumardi Azra bukan hanya karena kemampuan pesantren yang dapat melakukan adjusment dan readjustment, tetapi juga oleh kultur jawa, dimana pesantrenitu berada, yang mampu menyerap kebudayaan luar melalui proses internalisasi dengan tetap mempertahankan identitasnya. Halini sebagai bukti bahwa pesantren muncul danberkembang dari pengalaman sosiologis masyarakat ${ }^{4}$ Senada dengan pendapat tersebut, Sumarsono Mestoko menyarankan bahwa ketahanan pesantren disebabkan oleh melembaganya pesantren dalam masyarakat. ${ }^{5}$

Di dunia pesantren ilmu-ilmu agama diajarkan oleh para ustadz dan ustadzah bahkan kyai sebagai penggerak dalam perkembangan para santrinya. Pesantren memiliki peran yang tidak dapat diragukan lagi sebagai lembaga pusat penyaluran ilmu-ilmu keislaman yang di dalamnya banyak diajarkan nilai-nilai keislaman sebagai sarana dan tempat mencetak para pakar Agama dan pewaris Nabi untuk

\footnotetext{
${ }^{2}$ Imam Tokhah dan Barizi, Membuka Jendela Pendidikan: Mengurai Akar Tradisi, (Jakarta: PT. Raja GrafindoPersada, 2004), hlm. 49.

${ }^{3}$ Rustam Ibrahim, Bertahan di Tengah Perubahan: Pesantren Salaf, Kiai dan Kitab Kuning, (Jogjakarta:SIBUKU, 2005), hIm. 4-5.

${ }^{4}$ Azyumardi Azra, Pendidikan Islam: Tradisi dan Modernisasi di Tengah Tantangan Millenium III, (JakartaKencana Prenada media Grup. 2012), hlm. 130-131.
}

${ }^{5}$ Sumarso Mestoko et al..,Pendidikan di Indonesia dari jaman ke jaman, (Jakarta: Balai Pustaka, 1986), Im. 232. 
menghilangkan kebodohan di kalangan masyarakat. Namun sangat disayangkan dalam realitanya pembelajaran kitab kuning selama ini yang terjadi, masih banyaknya ditemukan yang belum mencapai kapasitas yang setara antara keahlian berbahasa dengan kemampuan metodologis pembelajaran Nahwu-Shorof, sehingga tidak mampu mengajarkan materi dengan cakap. Pengajar Nahwu-Shorof yang kurang cakap dalam mengajarnya akan menyebabkan kurang optimalnya dalam memenuhi kebutuhan peserta didiknya. Kenyataan ini banyak membawa konsekuensi yang serius sehingga banyak kegagalan dalam pembelajaran Nahwu-Shorof dan banyak dari santri yang belum bisa membaca kitab kuning hal ini akan mempengaruhi dalam proses maupun hasil pembelajaran itu sendiri yang pada akhirnya akan sulit untuk dipahami oleh santri. Semuanya menandakan akan pentingnya sebuah cara ataupun metode pembelajaran karena keberhasilan para santri dalam pembelajaran kitab kuning tergantung kecermatan dalam memilih metode untuk diterapkan dalam penyampaian materi. Hal tersebut merupakan problematika yang melanda dunia pendidikan pesantren, namun juga banyak pondok pesantren yang cerdas dalam memilah metodemetode pembelajaran Nahwu-Shorof. Mereka mengkolaborasikan metode klasik dengan metode pembelajaran yang modern, bahkan dengan pembelajaran model tersebut menjadikan para santrinya mudah dalam memahami pembelajaran yang sebelumnya cukup merumitkan para santrinya sehingga hal ini akan memudahkan mereka dalam mempelajari kitab-kitab para ulama baik yang klasik maupun yang kontemporer sebagai bekal pengetahuan dan wawasan akan ajaran agama yang dalam sehingga meningkatkan religiusitas santri yang mempelajarinya. Seperti di salah satu pondok pesantren yang peneliti jadikan sebagai objek penelitian yakni, Pondok Pesantren Apik Kecamatan Kesugihan Kabupaten Cilacap.

Pondok pesantren diakui sebagai model pendidikan awal (Islam) di Indonesia sampai saat ini masih eksis dan mampu mempertahankan kredibilitasnya di masyarakat. Meski demikian, peran pesantren saat ini boleh dikatakan sangat terbatas karena pengelolaan (Management) yang kurang kredibel, fasilitas kurang memadai serta kurangnya evaluasi dalam segala kegiatannya.

Manajemen dalam pondok pesantren agak berbeda dengan manajemen pada sekolah umum. Terutama Pondok Pesantren APIK yang penulis teliti yaitu memiliki karakteristik unik dalam perencanaan, pelaksanaan dan evaluasi pembelajaran Nahwu 
Shorof. Di Pondok Pesantren ini tidak dijumpai komponen-komponen pembelajaran formal, mata pelajaran yang diajarkan hanyalah ilmu keagamaan terutama kitab-kitab kuning atau kitab klasik. Metode pendekatannya seperti sorogan, bandongan, setoran atau hafalan, muthola'ah dan musyawarah.

Menurut keterangan Pengasuh Pondok Pesantren APIK seiring berkembangnya waktu, Pondok Pesantren APIK mulai memperbaiki manajemennya pada sistem pendidikan dan pengajarannya dengan menambahkan rencana pembelajaran dan evaluasi, administrasi sarana dan prasarana (perbaikan dan penambahan sarana prasarana untuk kegiatan proses kegaiatan belajar mengajar di pesantren. Administrasi santri (pengelolaan kegiatan santri baru, pengaturan santri, dokumentasi santri) dan evaluasi melalui perbaikan dari sistem Pondok Pesantren.

Sistem pembelajaran kitab kuning di Pondok Pesantren Apik mengkolaborasikan pembelajaran Nahwu Shorof dengan kitab kuning. Kitab yang digunakan menggunakan kitab-kitab yang berasal dari Saudi. Ada beberapa kitab yang diambil misal kitab Fiqih, Akhlaq, Aqidah, Hadits, Tafsir dan sebagainya yang semuanya menggunakan Bahasa Arab gundul diharapkan agar para santri bukan hanya mempelajari isi kandungannya namun juga mempelajari kedudukan dan harokat akhir kata di dalam tulisan Arab gundul atau tanpa harokat dan juga menambah kata-kata bahasa Arab baru untuk dihafalkan dan diterapkan pada kehidupan sehari-hari di pesantren. Dalam pembelajaran nahwu-Shorof maupun dalam pembelajaran diniyah lainnya para ustadz pengajar menyelipkan pembahasan terkait nahwu- Shorof yaitu tentang kedudukan per-katanya beserta harokatnya sehingga dengan sendirinya santri akan terlatih secara teori dan praktek. Untuk melakukan penelitian tersebut, peneliti sengaja memilih Pondok Pesantren Apik, peneliti tertarik untuk melakukan penelitian lapangan lebih jauh dengan dilatarbelakangi permasalahan yang muncul di pondok pesantren saat ini dalam pembelajaran kitab kuning. Penulis mencoba mengkaji dan meneliti; bagaimana penerapan pembelajaran Nahwu-Shorof untuk meningkatkan kualitas membaca kitab kuning di pesantren ini ?. Hal ini dirasa penting karena sejauh yang penulis ketahui bahwa pembelajaran yang terkandung di Nahwu-Shorof membahas secara detail tentang aspek yang dibutuhkan santri sebagai tambahan dan penguatan untuk mempermudah dalam mempelajari kitab kuning, dibutuhkan juga metode yang tepat baik dalam metode maupun cara penyampaiannya. Dengan 
ketertarikan peneliti akan permasalahan ini maka, penulis mengambil judul "Manajemen Pembelajaran Nahwu Shorof di Pondok Pesantren APIK Kecamatan Kesugihan Kabupaten Cilacap”. Menurut Sanjaya bahwa metode pembelajaran adalah cara yang digunakan untuk mengimplementasikan rencana yang sudah disusun dalam kegiatan nyata agar tujuan yang telah disusun tercapai secara optimal. ${ }^{6}$

Sedangkan menurut Sudjana metode pembelajaran ialah setiap upaya sistematik yang dipergunakan guru dalam mengadakan hubungan dengan siswa pada saat berlangsungnya pengajaran. Dalam pengertian luas, metode belajar mencakup perencanaan dan segala upaya yang bisa ditempuh dalam rangka pencapaian tujuan belajar mengajar secara efektif dan efisien. Karena metode mencakup segala aspek dalam proses pembelajaran, maka pemilihan metode yang sesuai dengan tujuan pembelajaran menjadi proses utama. Perencanaan metode yang tersusun dengan baik, pada akhirnya akan sangat mebantu guru dalam proses pembelajaran, dengan kata lain acuan yang akan digunakan oleh guru yaitu metode itu sendiri. ${ }^{7}$

Sebagai salah satu pesantren salaf yang ada di Kecamatan Kesugihan Kabupaten Cilacap ini, Pondok Pesantren APIK Kesugihan mewajibkan para santri untuk mempelajari kitab kuning, khususnya kitab Nahwu Shorof, para santri akan sangat terbantu dalam memahami Al-Qur'an dan Hadits dan kitab-kitab lain. Karena, salah satu misi dari Pondok Pesantren APIK Kecamatan Kesugihan Kabupaten Cilacap yaitu mencetak generasi muda yang berakhlaq mulia. Yang mana, para santrinya akan lebih mudah memahami ajaran islam yang ada di dalam Al-Quran dan Al Hadits.

Metode pembelajaran dapat dianggap sebagai suatu prosedur atau proses yang teratur, suatu jalan atau cara yang teratur untuk melakukan pembelajaran. Pembelajaran akan menjadi efektif dan menyenangkan apabila metode yang digunakan sesuai dengan keadaan peserta didik dan tujuan belajar, sehingga materi akan mudah dipahami dengan baik oleh peserta didik. Jadi, secara singkat peranan metode dalam pembelajaran menurut Suyono yaitu: (1) Sebagai pedoman bagi guru dalam perencanaan pembelajaran, (2) Sebagai alat untuk mencapai tujuan pembelajaran, (3)

\footnotetext{
${ }^{6}$ Wina Sanjaya. Strategi Pembelajaran Berorientasi Standar Proses Pendidikan. (Jakarta: Prenadamedia Group, 2016), hlm. 147.

${ }^{7}$ Nana Sudjana. Penilaian Hasil dan Proses Belajar Mengajar. (Bandung: Rosda Karya, 2011), hlm. 76.
} 
Sebagai salah satu cara agar pembelajaran berlangsung secara menyenangkan, (4) Sebagai salah satu cara agar dengan pemilihan metode yang tepat materi pembelajaran dapat diterima oleh siswa dengan baik.

Salah satu dari sekian metode pembelajaran ialah metode setoran atau hafalan kitab- kitab Nahwu Shorof. Metode setoran ini merupakan salah satu metode tradisional dan juga sekaligus metode andalan dalam pembelajaran Nahwu Shorof, yang sampai saat ini masih digunakan di Pondok Pesantren APIK Kecamatan Kesugihan Kabupaten Cilacap untuk mengatasi permasalahan pembelajaran tersebut. Metode setoran atau hafalan kitab Nahwu Shorof al al-ajurumiyyah, al 'imrithi dan alfiyyah ibnu malik yang diterapkan saat ini diharapkan mampu memberikan solusi terhadap kebutuhan pengajaran yang harus mengakomodasi seluruh kepentingan dan kemampuan santriwan dan santriwati serta memiliki manfaat yang sangat baik untuk mempermudah dalam memahami kitab kuning serta pemahaman ilmu Nahwu Shorof, dan terjemah bagi santri.

Dengan berkembangnya waktu dalam Pondok Pesantren juga melalui mengembangkan cara pembelajaran seperti mengembangkan metode-metode dalam pembelajaran yang dengan ini diharapkan dapat mempermudah santri dalam menerimapembelajaran yang disampaikan oleh guru. Metode pembelajaran yang digunakan yaitu :

1. Metode Hafalan, yaitu metode santri dengan cara menghafalkan nadzomannadzoman sesuai dengan kelasnya masing-masing santri yang kemudian santri menyetorkan kepada gurunya.

2. Metode Bandongan, yaitu seorang kyai atau guru membacakan, mengartikan dan menjelaskan isi sebuah kitab yang sedang dikaji dan diikuti oleh seluruh santrinya, dan masing-masing santri memegang kitab sendiri-sendiri untuk di asah-asahi (ditulis pegon miring) para santri mendengarkan dan terus mencatat apa yang sedang dibacakan dan diterangkan oleh kyai (gurunya).

3. Metode Bahtsul Masail, yaitu sebuah kegiatan diskusi metode ini biasanya berangkat dari suatu persoalan yang muncul dalam kehidupan sehari-hari para santri baik putra mapun putri atau muncul dari kaum muslimin maupun muslimat seperti 
contoh mudah yaitu masalah hukum kepemimpinan seorang perempuan itu bagaimana dan masih banyak contoh masalah-masalah yang lain.

Namun, metode-metode ini juga memiliki kelemahan, sehingga perlu diadakan evaluasi untuk mengkaji ulang seberapa efektif metode setoran ini dalam mengatasi permasalahan pembelajaran. Dan juga perlu pertimbangan untuk terus menggunakan metode ini ataupun memberikan rekomendasi yang membangun dalam pelaksanaan metode setoran ini sehingga dapat mewujudkan tujuan pembelajaran yang lebih baik lagi.

Peneliti sangat tertarik untuk meneliti di Pondok Pesantren APIK karena pesantren ini dalam manajemen pembelajarannya terutama Nahwu Shorofnya baik dari segi perencanaan, pelaksanaan, maupun evaluasinya cukup baik dibuktikan dengan perbaikan-perbaikan sistem pendidikan yaitu kurikulum, menambah materi pembelajaran kitab lain dan menambah sarana prasarana seperti perpustakaan untuk kelancaran proses kegiatan belajar mengajar di pesantren serta banyak prestasi yang telah diraih oleh para santri APIK terutama di ajang lomba-lomba hafalan kitab Nahwu Shorof dan lomba baca kitab kuning sebagai bukti bahwa proses belajar mengajar berjalan sesuai dengan perencanaan yang ditentukan pada awal pembelajaran. Selain itu peneliti tertarik melakukan penelitian di Pondok Pesantren APIK karena mempunyai beberapa keunikan antara lain yaitu :

1. Menggunakan kurikulum sendiri, yaitu kurikulum yang disepakati oleh kyai dan para ustadz serta kepala Madrasah Diniyah (MADIN) Pondok Pesantren APIK.

2. Materi pembahasannya yang lebih khas yaitu ilmu alatnya (Nahwu Shorof) tetapi tetap mempelajari kitab-kitab lain. Dengan dibuktikan logo Pondok APIK yang tertera bertuliskan (Attarbiyatun Nahwiyatus Salafiyah).

3. Menggunakan metode pembelajaran yang disesuaikan dengan materi pembelajaran oleh pengasuh dan dewan asatidz

4. Adanya ujian micro teaching dan ujian munaqosah bagi santri kelas 3 dan diawasi atau di nilai langsung oleh pengasuh dan dewan asatidz keluarga ndalem.

Dari alasan ketertarikan penelitian yang penulis lakukan yaitu untuk mengetahui bagaimana manajemen pembelajaran Nahwu Shorof di Pondok Pesantren APIK saat 
ini dan untuk seterusnya. Oleh karena itu penulis melakukan penelitian dengan memilih judul "Manajemen Pembelajaran Nahwu Shorof di Pondok Pesantren APIK Kecamatan Kesugihan Kabupaten Cilacap". Penelitian ini bertujuan untuk mendeskripsikan dan menganalisis pembelajaran Nahwu Shorof di Pondok Pesantren APIK Kecamatan Kesugihan Kabupaten Cilacap.

\section{KAJIAN LITERATUR}

\section{Manajemen Pembelajaran}

Menurut Sulistyorini bahwa "Manajemen adalah suatu hal penting yang menyentuh, mempengaruhi dan bahkan merasuki hampir seluruh aspek kehidupan manusia layaknya darah dan raga. Juga telah dimengerti bahwa dengan manajemen, manusia mampu mengenali kemampuannya berikut kelebihan dan kekurangannya sendiri”. Manajemen menunjukkan cara-cara yang lebih efektif dan efisien dalam pelaksanaan suatu pekerjaan. Manajemen telah memungkinkan kita untuk mengurangi hambatan-hambatan dalam rangka pencapaian suatu tujuan. Manajemen juga memberikan prediksi dan imajinasi agar kita dapat mengantisipasi perubahan lingkungan yang serba cepat. ${ }^{8}$

Istilah manajemen mengacu kepada proses mencapai tujuan secara efisien dengan dan melalui pendayagunaan sumber daya organisasi. Menurut Longnecker $\&$ Pringle, merumuskan manajemen sebagai proses memperoleh dan menggabungkan sumber-sumber manusia, finansial dan fisik untuk mencapai tujuan pokok organisasi menghasilkan produk atau jasa/layanan yang diinginkan oleh sekelompok masyarakat. ${ }^{9}$

Manajemen yang sangat penting dalam pembelajaran yaitu manajemen sumber daya manusia, karena manajemen sumber daya manusia merupakan salah satu bidang dari manajemen umum yang meliputi segi-segi perencanaan, pengorganisasian, pelaksanaan dan pengendalian. Karena sumber daya manusia dianggap semakin penting peranannya dalam pencapaian tujuan, maka berbagai pengalaman dan hasil penelitian dalam bidang sumber daya manusia. Istilah "manajemen"mempunyai arti

\footnotetext{
${ }^{8}$ Sulistyorini, Manajemen Pendidikan Islam, Konsep, Strategi dan aplikasi (Yogyakarta: Teras, 2009), hlm. 7

${ }_{9}^{9}$ Marno dan Triyo Supriyatno, Manajemen dan Kepemimpinan Pendidikan Islam, (Bandung: PT. Refika Aditama), cetakan kedua 2013, hlm. 1
} 
sebagai kumpulan pengetahuan tetang bagaimana seharusnya memanage (mengelola) sumber daya manusia ${ }^{10}$

Selanjutnya, fungsi-fungsi manajemen pembelajaran yang dibahas dalam penelitian ini meliputi: (1) perencanaan pembelajaran, (2) pelaksanaan pembelajaran, dan (3) evaluasi pembelajaran. Berikut ini penulis uraikan masing-masing.

\section{Pelaksanaan Pembeajaran}

Perencanaan merupakan salah satu hal penting yang perlu dibuat untuk setiap usaha dalam rangka mencapai suatu tujuan. Karena seringkali pelaksanaan suatu kegiatan akan mengalami suatu kesulitan baik itu dalam pendidikan formal maupun non formal (di sekolah maupun di Pondok Pesantren) dalam mencapai tujuan tanpa adanya sebuah perencanaan yang matang.

Perencanaan adalah penentuan secara matang dan cerdas tentang apa yang akan dikerjakan dimasa yang akan datang dalam rangka mencapai tujuan. Menurut Anderson dan Bowman mengatakan bahwa perencanaan adalah proses mempersiapkan seperangkat keputusan bagi perbuatan di masa datang. Definisi ini mengisyaratkan bahwa pembuatan keputusan merupakan bagian dari perencanaan, namun proses perencanaan dapat juga terpikir setelah tjuan dan keputusan diambil. ${ }^{11}$

\section{Pelaksanaan Pembelajaran}

Pelaksanaan pembelajaran merupakan fungsi manajemen yang paling utama. Dalam fungsi perencanaan dan pengorganisasian lebih banyak berhubungan dengan aspek-aspek abstrak proses manajemen, sedangkan fungsi actuating justru lebih menekankan pada kegiatan yang berhubungan langsung dengan orang-orang dalam oranisasi. George R. Terry mengemukakan bahwa pelaksanaan merupakan usaha menggerakkan anggota-anggota kelompok sedemikian rupa hingga mereka berkeinginan dan berusaha untuk mencapai sasaran perusahaan dan sasaran anggotaanggota perusahaan tersebut karena para anggota itu juga ingin mencapai sasaransasaran tersebut. Dari pengertian diatas, pelaksanaan (actuating) tidak lain merupakan upaya untuk menjadikan perencanaan menjadi kenyataan, dengan melalui berbagai

\footnotetext{
${ }^{10}$ Chusnul Chotimah dan Muhammad Fathurrohman, Komplemen Manajemen Pendidikan Islam, Konsep Integratif Pelengkap Manajemen Pendidikan Islam. (Yogyakarta: Teras, 2014), hlm. 130

${ }_{11}$ Marno dan Triyo Supriyatno, Op.Cit., hlm. 13-14.
} 
pengarahan dan pemotivasian agar setiap karyawan dapat melaksanakan kegiatan secara optimal dengan peran, tugas dan tanggung jawabnya. ${ }^{12}$

\section{Evaluasi Pembelajaran}

Evaluasi pembelajaan merupakan langkah yang penting untuk memperoleh informasi mengenai hasil pembelajaran. Informasi mengenai ketercapaian tujuan pembelajaran yang telah ditetapkan, khususnya yang terkait dengan keberhasilan peserta didik dalam proses pembelajaran. Melalui evaluasi akan diketahui apakah materi pembelajaran menjadi alat yang tepat untuk mencapai tujuan pembelajaran menjadi alat yang tepat untuk mencapai tujuan pembelajaran. Apakah metode dan media telah efektif mendorong proses pembelajaran mencapai tujuannya. ${ }^{13}$

Evaluasi merupakan salah satu sarana penting dalam meraih tujuan belajar mengajar. Guru sebagai pengelola kegiatan belajar mengajar dapat mengetahui kemampuan yang dimiliki siswa, ketepatan metode mengajar yang digunakan, dan keberhasilan siswa dalam meraih tujuan pembelajaran yang telah ditetapkan melalui kegiatan evaluasi. Guru dapat mengambil keputusan secara tepat dengan informasi ini mengenai langkah apa yang harus dilakukan selanjutnya. Informasi tersebut juga dapat memberikan motivasi kepada siswa untuk berprestasi lebih baik. Ujian try out pada hakikatnya merupakan evaluasi hasil belajar yang dilaksanakan oleh lembaga pendidikan sebelum menghadapi Ujian Nasional (UN).

Berdasarkan uraian di atas, maka dapat dipahami bahwa manajemen pembelajaran dalam penelitian ini adalah merupakan proses merencanakan, melaksanakan dan mengevaluasi segala kegiatan dengan optimal untuk mencapai tujuan secara efektif dan efisien. Proses merencanakan yang dimaksud adalah proses merencanakan program pembelajaran nahwu shorof, bagaimana jalannya proses kegiatan belajar mengajar dan bagaimana pelaksanaan kegiatan serta evaluasi pembelajaran untuk mencapai sebuah tujuan program pembelajaran nahwu shorof di Pondok Pesantren APIK Kesugihan.

\section{Pembelajaran Nahwu Shorof}

\footnotetext{
${ }^{12}$ Rusman, Manajemen Kurikulum, Edisi kedua (Jakarta: PT. Raja Grafindo Persada), 2019, hlm. 119.

${ }^{13}$ Hartono, Pendidikan Integratif (Purwokerto: STAIN Press, 2011), hlm. 51
} 
Ilmu Nahwu terfokus mempelajari seputar struktur (susunan kalimat serta harokat) dalam Bahasa Arab yang baik dan benar. Ilmu Shorof mempelajari berbagai perubahan bentuk kata ke bentuk kata yang lainnya. Sedangkan Ilmu Shorof menentukan perubahan- perubahan bentuk kata dari satu bentuk ke bentuk lainnya.

Pembelajaran Nahwu Shorof di pondok pesantren memiliki keunikan tersendiri selain dari pada penggunaan metode khas pesantren juga dikarenakan banyaknya keilmuan yang diajarkan di pondok pesantren. Orientasi pembelajaran di pondok pesantren bukan hanya terkait ketuntasan pembelajaran saja tetapi juga didukung oleh kriteria pemahaman santri dari apa yang dia pelajari. (W.ASY.URM.2)

Ada beberapa keilmuan bahasa Arab yang harus dipelajari bagi seseorang yang ingin memahami bahasa Arab, antara lain Nahwu dan Shorof. Nahwu merupakan ilmu bahasa Arab yang dipelajari untuk mengetahui kedudukan kata dalam kalimat dan perubahan baris akhir. Sedangkan Shorof adalah ilmu yang mempelajari tentang asalusul kata, sehingga dapat mengetahui arti suatu kata. Kedua ilmu bahasa ini selalu dipergunakan untuk memperoleh kemahiran berbahasa Arab dengan benar sesuai dengan kaidah bahasa, dan untuk menghindari kesalahan-kesalahan dalam membaca, berbicara, dan menulis.

Ada beberapa hal yang harus diperhatikan dalam mengajar Nahwu dan Shorof, antara lain : 1) banyak memberikan contoh-contoh dari materi yang dibahas, agar pengajaran tidak membosankan dan mudah dimengerti peserta didik; 2) contoh yang diberikan ditulis di papan tulis dan dijelaskan maksudnya; 3) penjelasan materi dihubungkan dengan ilmu bahasa dan kemahiran berbahasa Arab lainnya. ${ }^{14}$

Jadi dapat diambil kesimpulan bahwa pembelajaran nahwu shorof di sekolah maupun di pondok pesantren itu harus menggunakan metode atau cara yang sangat menarik agar dalam menyampaikan materi dapat dipahami dengan mudah oleh para siswa atau santri sesuai dengan kemampuan para ustadz dan ustadzahnya.

\section{Pondok Pesantren}

Muzayin Arifin mendefinisikan pesantren adalah sebagai suatu lembaga pendidikan agama yang tumbuh serta diakui oleh masyarakat sekitar, dengan sistem

\footnotetext{
${ }^{14}$ Khalilulloh, Media Pembelajaran Bahasa Arab (Yogyakarta: Aswaja Pressindo, tanpa tahun), hlm. 10
} 
asrama. ${ }^{15}$ Pondok pesantren secara etimologi diambil dari bahasa Arab, funduk yang berarti rumah penginapan atau hotel ${ }^{16}$ Dalam bahasa Indonesia, Pesantren berasal dari akar kata santri dengan awalan Pe dan akhiran an yang berarti tempat tinggal santri. Santri adalah para pelajar yang tinggal danmengaji di pesantren. Kata santri diambil dari bahasa Tamil yang berarti gurumengaji. Selain itu, ada yang berpendapat bahwa istilah santri berasal dari Bahasa India, shastri, yang berarti orang yang tahu buku-buku suci Agama Hindu, atau seorang sarjana ahli kitab suci Agama Hindu. Dan kata shastri sendiri berasal dari kata shastra yang berarti buku-buku suci, buku-buku agama atau buku-buku tentang ilmu pengetahuan. ${ }^{17}$ Menurut Arief Subhan, santri itu berarti "terpelajar" (learned) atau "ulama" (scholar). ${ }^{18}$ Sedangkan menurut Azyumazri Azra, santriadalah mereka yang berasal dari pesantren, atau arti yang lebih umum adalah mereka yang menjalankan ajaran Islam. ${ }^{19}$ Selain itu, terkadang pesantren dianggap gabungan dari kata sant yangberarti manusia baik dengan suku kata ira yang berarti suka menolong, sehingga pesantren dapat berarti tempat pendidikan manusia yang baik-baik. ${ }^{20}$

Secara terminologis, pesantren adalah lembaga pendidikan Islam yang asli Indonesia yang memiliki kekhasan tersendiri dan berbeda dengan lembaga pendidikan lainnya dalam menyelenggarakan sistem pendidikan, pengajaran agama serta mengembangkan dan menyebarkan ilmu agama islam dan merupakan warisan kekayaan bangsa Indonesia yang terus berkembang. ${ }^{21}$ Dalam bahasa lain pesantren merupakan lembaga yang tidak hanya identik dengan makna keislaman, tetapi juga mengandung makna keaslian Indonesia (indigenous). ${ }^{22}$ Yang berarti memiliki khas tersendiri yang hanya ada di Indonesia.

\footnotetext{
${ }^{15}$ Fathul Aminudin Aziz, Manajemen Pesantren (Purwokerto: STAIN Press, 2014), hlm. 7

${ }^{16}$ Manfredziemek, Pesantrendalam Perubahan Sosial, (Jakarta: P3M,1986), hlm. 98-99

${ }^{17}$ Zamakhsyari Dhofier, Tradisi Pesantren: Studi tentang Pandangan Hidup Kyai. (Jakarta: LP3ES, 2011), hlm. 41.

${ }^{18}$ Arief Subhan, Lembaga Pendidikan Islam Indonesia Abad ke-20: Pergumulan antara Modernisasi dan Identitas, (Jakarta: Kencana,2012), hlm.75

${ }^{19}$ Azyumazri Azra, Pendidikan Islam: Tradisi dan Modernisasi Menuju Milenium Baru, (Jakarta: Logos Wacana Ilmu, 1999), hlm 69.

${ }^{20}$ Wahjoetomo, PerguruanTinggiPesantren, (Jakarta: Gema InsaniPress,1997), hlm.5

${ }^{21}$ Ridwan Natsir, Mencari Tipologi Format Pendidikan Ideal: Pondok Pesantren di Tengah Arus Perubahan, (Yogyakarta: Pustaka Pelajar, 2005), hlm.80

${ }^{22}$ Nurcholis Madjid, Bilik-bilik Pesantren, (Jakarta: Paramadina,1997), hlm.3
} 
Menurut Muhammad Hambal Shafwan, pesantren adalah lembaga pendidikan tradisional Islam untuk memahami, menghayati, dan mengamalkan ajaran-ajaran agama Islam (tafaqquh fiddin) dengan bermasyarakat sehari-hari. ${ }^{23}$

Pondok pesantren adalah sebuah lembaga yang tidak bisa terlepas dari fenomena kerjasama, mengingat Ponpes adalah perwujudan dari cita-cita atau keinginan mencipta kader penerus atau santri yang ahli dibidang ilmu pengetahuan, khususnya ilmu pengetahuan agama. Pesantren juga sekaligus harus mewujudkan kemampuan untuk mengembangkan dan mengamalkan ilmu pengetahuan agama tersebut ditengahtengah masyarakat. Cita-cita atau keinginan luhur tersebut sulit terwujud bila hanya dilakukan oleh seorang kiai/pengasuh, karena secara kodrat manusia memang mempunyai keterbatasan, sehingga diperlukan keterlibatan berbagai manusia melalui proses kerjasama dalam mewujudkan cita-cita atau keinginan tersebut. ${ }^{24}$

Jadi dapat diambil kesimpulan bahwa pesantren adalah suatu lembaga pendidikan khas Indonesia yang menampung para santri untuk memahami, menghayati dan mengamalkan ajaran-ajaran agama Islam yang memiliki kekhasan tersendiri dan berbeda dengan lembaga pendidikan yang lainnya.

Dan bisa disimpulkan lagi dari beberapa teori pesantren diatas bahwa Pondok adalah sebuah kamar, gubuk, atau rumah kecil seperti bangunan sederhana yang merupakan lembaga pendidikan non formal dimana para santri atau murid tinggal di asrama dengan menekuni atau mengkaji kitab-kitab salaf seperti Nahwu, Shorof, Tajwid, mabadiul fiqhiyyah, safiinatunnajah, kitab kuning yang lainnya. Yang tujuannya untuk memperdalam dan menguasai ilmu agama Islam secara detail. Serta nantinya para santri bisa mengamalkannya baik untuk diri sendiri maupun untuk masyarakat sekitar.

Sementara itu situasi umum yang dihadapi oleh pesantren adalah situasi kejiwaan, yaitu rasa tak menentu yang biasa disebut sebagai keadaan rawan. Ini disebabkan oleh beberapa faktor yang antara lain adalah: (1) Kesadaran akan sedikitnya kemampuan untuk mengatasi tantangan-tantangan yang dihadapi pesantren, terutama tantangan yang diajukan oleh kemajuan teknik yang dienyam bangsa kita. (2)

\footnotetext{
${ }^{23}$ Muhammad Hambal Shafwan, Inti Sari Sejarah Pendidikan Islam, (Solo: Putaka Arafah, 2014), hlm. 255-256

${ }^{24}$ A. Halim, Suhartini, M. Choirul Arif, dan A. Sunarto AS, Manajemen Pesantren, (Yogyakarta: Pustaka Pesantren, 2009), hlm. 50-51.
} 
Statis/bekunya struktur sarana-sarana yang dihadapi pesantren pada umumnya, baik soal sarana yang berupa manajemen/pimpinan yang terampil maupun sarana material (termasuk keuangan), masih berada pada kuantitas yang sangat terbatas. Keterbatasan sarana-sarana itu membawa akibat tidak mungkin dilakukannya penanganan kesulitan yang dihadapi secara integrl dan menyeluruh. ${ }^{25}$

\section{METODE PENELITIAN}

Pendekatan yang digunakan dalam penelitian ini adalah kualitatif studi kasus. Tempat penelitian di Pondok Pesantren APIK yang beralamatkan di Jalan Kebon Salak Rt. 02 Rw. 06 Kecamatan Kesugihan Kabupaten Cilacap. Sedangkan waktu penelitian yaitu pada awal bulan Desember 2020 sampai akhir bulan Mei 2021.

Dalam penelitian ini ada dua informan primer yaitu guru dan santri. Guru sebagai subyek atau pelaku motivasi dan santri sebagai obyek yang dimotivasi. Termasuk guru di sini adalah pengelola dan koordinator yang tidak selalu bertugas mengajar santri secara langsung. Sedangkan santri di sini mencakup santri yang masih di pondok dan santri yang sudah alumni. Selain itu juga peristiwa digunakan peneliti untuk mengetahui proses bagaimana sesuatu secara lebih pasti karena menyaksikan sendiri secara langsung. Contohnya jalannya pembelajaran, program-program yang dijalankan, dan lain-lain. Di sini peneliti akan melihat secara langsung peristiwa yang terjadi terkait dengan metode guru memotivasi santri dalam pembelajaran nahwu Shorof di Ponpes APIK Kecamatan Kesugihan Kabupaten Cilacap.

Data penelitian dikumpulkan melalui wawancara mendalam, observasi partisipan, dan analisis dokumen. Untuk mengetahui bahwa data yang dikumpulkan dalam penelitian ini adalah benar, maka dilakukan uji keabsahan data menggunakan teknik triangulasi. Selanjutnya, data penelitian ini dianalisis menggunakan teknik analisis interaktif yang dikembangkan oleh Miles \& Huberman, yaitu: reduksi data, penyajian data, dan penarikan kesimpulan.

\section{HASIL DAN PEMBAHASAN}

1. Perencanaan Pembelajaran Nahwu Shorof di Pondok Pesantren APIK

\footnotetext{
25 Ibid., hlm. 51.
} 
Untuk tahap perencanaan pembelajaran nahwu shorof model pembelajarannya atau metode yang digunakan di Pondok Pesantren APIK pada awal berdiri kata Ustadzah Raounaqun Na'ma masih sangat tradisional, yaitu masih menggunakan metode sorogan, bandongan tanpa adanya RPP tertulis karena memang prinsip pondok pesantren APIK, yakni Tarbiyah an nahwiyyah as salafiyyah (pengajaran ilmu nahwu secara tradisional).

Namun seiring berkembangngnya zaman semakin maju dan harus adanya perubahan dalam perencanaan pembelajaran nahwu shorof di Pondok Pesantren APIK, di tahun 2020 ini semakin banyak kemajuan dalam memenej pembelajaran baik mata pelajaran nahwu shorof maupun mapel lain yakni salah satu langkah utama yang dilakukan oleh dewan asatidz hasil wawancara dengan Ustadzah Mamluatul Khiyarotil Banat sebagai salah satu pendukung kelancaran dan kesuksesan pelaksanaan kegiatan belajar mengajar Nahwu Shorof di Pondok Pesantren APIK adalah perencanaan yang berhubungan dengan sarana dan prasarana yang mendukung. Diantaranya peralatan menulis untuk ustadz atau ustadzahnya dalam menjelaskan materi nantinya. Ruangan yang bersih dan rapih dan yang paling penting dalam sebuah pembelajaran adalah RPP yang sudah disiapkan oleh dewan asaatidz sesuai dengan mata pelajaraan yang diampu juga harus dirapatkan terlebih dahulu agar nantinya pelaksanaan pembelajaran Nahwu Shorof bisa memenuhi target apa yang diinginkan oleh dewan asaatidz.

Perencanaan dalam pembelajaran kitab Nahwu Shorof di Pondok Pesantren APIK meliputi pembuatan perencanaan secara musyawarah bersama para ustadz, pembuatan jadwal pembelajaran di setiap kelas, pembagian tugas ustadz pengampu materi, kitab yang akan digunakan dan juga meliputi sarana prasarana sebagai penunjang pembelajaran di dalam kelas. Adapun yang menjadi hasil analisis penulis adalah segala kegiatan yang telah direncanakan untuk menunjang keberhasilan kegiatan belajar mengajar di Pondok Pesantren APIK kesugihan.

Dalam kegiatan perencanaan yang dilakukan pada sistem pendidikan di Pondok Pesantren APIK sudah mencakup segala hal yang diperlukan dalam pencapaian tujuan manajemen pembelajaran Nahwu Shorof. Selain itu langkah-langkah yang harus dilakukan dalam perencanaan juga sudah sesuai dengan harapan seperti rapat dewan asatidz dalam pembuatan rencana pembelajaran dan lain-lain. 
Dilihat dari perencanaan yang memuat kurikulum, yaitu rapat atau musyawarah kurikulum, pembuatan jadwal pelajaran beserta dewan asatidz yang mengampu telah disesuaikan dengan kemampuan asatidz, penentuan materi yang sudah sesuai standar pendidikan pesantren yang ada dan sudah disesuaikan dengan kemampuan para santri atau peserta didik yang ada di Pondok Pesantren APIK, kegiatan evaluasi belajar berupa penetapan tanggal pelaksanaan kegiatan evaluasi, penyusunan jadwal ujian, penetapan soal dan nilai hasil akhir serta pemberian sarana dan prasana untuk menunjang kegiatan evaluasi

tersebut yang sudah disesuaikan dengan jumlah peserta didik yang ada. Hanya saja kurang adanya perencanaan yang terkait dengan metode pengajaran yang dilakukan sebelum kegiatan belajar mengajar. Akhirnya dapat diambil kesimpulan bahwasannya kegiatan perencanaan pembelajaran Nahwu Shorof yang ada di Pondok Pesantren APIK sudah terbilang cukup bagus hanya saja RPP belum tertulis secara fomal seperti perencanaan- perencanaan yang ada di lembaga pendidikan formal.

Ada sembilan ruang yang digunakan dalam kegiatan belajar mengajar di MADIN APIK. Dalam masing-masing ruang atau kelas dilengkapi media pembelajaran seperti : meja untuk dewan asatidz, whiteboard beserta spidol dan penghapus, dan juga disediakan sebuah perpustakaan sebagai bahan pendukung para santri agar lebih senang dengan membaca sesuai dengan firman Alloh dalam al qur'an yang pertama kali diturunkan kepada nabi muhammad SAW yaitu perintah tentang membaca. Karena membaca adalah jendela ilmu dan menambah lebih banyak pengetahuan selain pengetahuan dari para ustadznya. ${ }^{26}$

Sampai pada pelaksanaan evaluasi atau ujian pembelajaran Nahwu Shorof atau pelajaran kitab lain, pengurus dan dewan asatidz menyiapkan sarana dan prasarana untuk kelancaran kegiatan evaluasi tersebut, seperti kelengkapan nomor ujian, kartu ujian peserta dan jadwal ujian, menentukan pengawas serta panitia ujian dan yang paling mendukung adalah tempat atau kelas yang bersih agar para santri merasa nyaman berada di dalam ruangan ketika sedang mengerjakan soal ujian, hal ini

\footnotetext{
${ }^{26}$ Wawancara dengan ustadzah Rounaqun Na'ma, tanggal 5 Maret 2021, pukul 13.00-14.00 WIB
} 
dilakukan untuk mempermudah santri dalam kegiatan pelaksanaan ujian baik ujian nisfu sanah maupun akhirus sanah. ${ }^{27}$

\section{Pelaksanaan Pembelajaran Nahwu Shorof di Pondok Pesantren APIK}

Berdasarkan penelitian yang penulis peroleh dari observasi, wawancara dengan pengasuh dan para ustadz yang ada di Pondok Pesantren APIK bahwa pelaksanaan sistem pendidikan di Pondok APIK sudah sesuai dengan jadwal yang telah ditulis oleh pengurus dan materi serta kitab yang digunakan oleh pengampu juga sudah sesuai dengan standar pendidikan Madrasah Diniyah (Madin) dan kemampuan santri.

Pelaksanaan proses pembelajaran di Madrasah Diniyah APIK Kesugihan dilakukan oleh santri-santri di Pondok Pesantren APIK dan dewan asaatidz pada pukul 19.00-21.00 yang dibagi menjadi 2 jam pelajaran yaitu pukul 19.00-20.00 dan 20.0021.00 WIB. Kegiatan ini telah disesuaikan dengan jadwal kegiatan yang sebelumnya telah dirapatkan atau diterapkan dan dibuat oleh kepala Madin serta dewan asaatidz.

Materi pembelajaran dan Metode pengajaran yang dilakukan masing-masing dewan asatidz sudah disesuaikan dengan kurikulum yang diharapkan oleh Kementrian Agama, pembuatan soal yang dibuat telah sesuai dengan tingkat kelas dan sesuai dengan materi yang telah disampaikan oleh ustadz pengampu. Untuk itu penulis mengambil kesimpulan bahwa pelaksanaan pembelajaran Nahwu Shorof yang ada di Pondok Pesantren APIK sudah dilaksanakan sesuai dengan rencana adapun proses kegiatan pembelajaran nahwu shorofnya juga sudah dilaksanakan dengan sangat baik.

Untuk pelaksanaan ujian pembelajaran nahwu shorof dilakukan 2 kali dalam satu tahun yaitu tes nisfu sanah dan akhirus sanah. Ujian yang dilakukan yaitu ujian tertulis dan ujian praktik. Pada tes tertulis santri mengerjakan soal yang telah dibagikan oleh pengawas ujian pada lembar jawab yang telah disediakan. Pada ujian praktik terdiri dari ujian praktik ibadah seperti praktik wudlu untuk kelas 1 Madin, sedangkan untuk kelas 2 praktik sholat gerhana dan kelas 3 praktik memandikan dan mensholati jenazah. Pada ujian praktik Qiroatul Qur'an dan Qiroau kutub peserta didik atau santri mengambil sebuah lintingan yang berisi materi evaluasi yang telah ditentukan dan telah disampaikan kisi-kisinya oleh dewan asaatidz. Dan pada ujian hafalan nadzoman

\footnotetext{
${ }^{27}$ Wawancara dengan ustadzah Rounaqun Na'ma, tanggal 5 Maret 2021, pukul 13.00-14.00 WIB
} 
kitab-kitab nahwu shorof juga sudah sesuai dengan kelas atau tingkatan para santri. Kelas 1 menghafal kitab Al-Ajurumiyyah dan amtsilatut tasrifiyah, untuk kelas 2 menghafal nadzom Al-'Imrithi, sedangkan untuk kelas 3 menghafal kia Al- Maqsud dan kelas 4 kitab Alfiyah Ibnu Malik unuk batasan telah ditentukan dengan cara rapat antar dewan asatidz Madin APIK.

\section{Evaluasi Pembelajaran Nahwu Shorof di Pondok Pesantren APIK}

Hasil pembelajaran yang ada di Pondok Pesantren APIK Kesugihan berdasarkan teori di bab yaitu berupa tes atau ujian yang dilaksanakan dua kali dalam satu tahun yaitu tes nisfusanah dan tes akhirussanah. Tes atau ujian ini meliputi ujian tertulis dan ujian praktik (praktik ibadah, ujian hafalan, ujian qiro'atul qur'an, ujian qiro'atul kutub) dan khusus bagi peserta didik atau santri kelas III akan diadakan praktik mengajar (micro teaching) dan ujian di akhir semester untuk mendapatkan ijazah. Untuk kelas IV ditahun ini masih dalam tahap perbaikan pendidikan oleh karena itu kelas IV hanya mendapatkan materi pelajaran dan mengikuti tes akan tetapi tidak untuk kelulusan. Adapaun syarat mengikuti ujian adalah setiap peserta didik atau santri harus menguasai mata pelajaran Nahwu dan Shorof serta telah lulus praktik mengajar atau micro teaching.

Tabel 1. Jadwal Ikhtibar Akhirussanah Madin PP.APIK Putri Tahun Pelajaran 2020-2021 M/1441-1442 H

\begin{tabular}{|c|c|c|c|c|c|}
\hline \multirow[t]{2}{*}{ No } & \multirow[t]{2}{*}{ Hari/Tanggal } & \multirow[t]{2}{*}{ Waktu } & \multicolumn{3}{|c|}{ Mata Pelajaran } \\
\hline & & & Kelas I & Kelas II & Kelas III \\
\hline 1 & $\begin{array}{l}\text { Ahad, } \\
14-3-2021\end{array}$ & $\begin{array}{l}19.00-20.00 \\
20.00-21.00\end{array}$ & $\begin{array}{l}\text { Fiqih } \\
\text { Shorof }\end{array}$ & $\begin{array}{l}\text { Nahwu } \\
\text { Hadits }\end{array}$ & $\begin{array}{l}\text { Shorof } \\
\text { Tauhid }\end{array}$ \\
\hline 2 & $\begin{array}{l}\text { Senin, } \\
15-3-2021\end{array}$ & $\begin{array}{l}19.00-20.00 \\
20.00-21.00\end{array}$ & $\begin{array}{l}\text { Tajwid } \\
\text { Hadits }\end{array}$ & $\begin{array}{l}\text { Tafsir } \\
\text { Shorof }\end{array}$ & $\begin{array}{l}\text { Qowaidul } \\
\text { Akhlaq }\end{array}$ \\
\hline 3 & $\begin{array}{l}\text { Selasa, } \\
\text { 16-3-2021 }\end{array}$ & $\begin{array}{l}19.00-20.00 \\
20.00-21.00\end{array}$ & $\begin{array}{l}\text { Tafsir } \\
\text { Tauhid }\end{array}$ & $\begin{array}{l}\text { Tajwid } \\
\text { Fiqih }\end{array}$ & $\begin{array}{l}\text { Ilmu tafsir } \\
\text { Q.kutub }\end{array}$ \\
\hline 4 & $\begin{array}{l}\text { Rabu, } \\
17-3-2021\end{array}$ & $\begin{array}{l}19.00-20.00 \\
20.00-21.00\end{array}$ & $\begin{array}{l}\text { Akhlaq } \\
\text { Nahwu }\end{array}$ & $\begin{array}{l}\text { Tauhid } \\
\text { Tarikh }\end{array}$ & $\begin{array}{l}\text { Nahwu } \\
\text { Fiqih }\end{array}$ \\
\hline 5 & $\begin{array}{l}\text { Jum'at, } \\
19-3-2021\end{array}$ & $\begin{array}{l}19.00-20.00 \\
20.00-21.00\end{array}$ & $\begin{array}{l}- \\
\text { Tarikh } \\
\text { Imla' }\end{array}$ & $\begin{array}{l}\text { R.Mahidh } \\
\text { Muhafadzoh }\end{array}$ & $\begin{array}{l}\text { Praktik } \\
\text { ibadah } \\
\text { Ilmu hadits }\end{array}$ \\
\hline 6 & $\begin{array}{l}\text { Sabtu, } \\
\text { 20-3-2021 }\end{array}$ & $\begin{array}{l}19.00-20.00 \\
20.00-21.00\end{array}$ & $\begin{array}{c}\text { Qiroatul Q } \\
\text { Qiroatul } \\
\text { Kutub }\end{array}$ & $\begin{array}{l}\text { Akhlaq } \\
\text { Praktik } \\
\quad \text { ibadah }\end{array}$ & $\begin{array}{l}\text { Ushul Fiqh } \\
\text { Tafsir } \\
\text { Hadits }\end{array}$ \\
\hline
\end{tabular}




\begin{tabular}{|c|l|c|c|c|c|}
\hline 7 & $\begin{array}{l}\text { Ahad, } \\
21-3-2021\end{array}$ & $\begin{array}{c}19.00-20.00 \\
20.00-21.00\end{array}$ & $\begin{array}{c}\text { Praktik } \\
\text { ibadah } \\
\text { Muhafadzoh }\end{array}$ & $\begin{array}{c}\text { Qiroatul Q } \\
\text { Qiroatul } \\
\text { kutub }\end{array}$ & $\begin{array}{c}\text { Muhafadzoh } \\
\text { Qiroatul Q }\end{array}$ \\
\hline
\end{tabular}

Keterangan :

Praktek Ibadah :

Kelas 1 : Sholat Fardlu

Kelas 2 : Sholat Jama' Qoshor

Kelas 3 : Memandikan \& Mengkafani jenazah Muhafadzoh :

Kelas 1 : Jurumiyyah (Na'at Akhir) Kelas 2 : 'Imrithi ( Na'at Akhir) Kelas 3 : Alfiyah (Awal Kaana) Qiroatul Kitab :

Kelas 1 : Safinah (An-Niyyaatu s/d Asbaabus Sujuudi) Kelas 2 : Sulam Taufiq (Watabthulu As sholaatu s/d Zakat) Kelas 3 : Taqrib (Faroid s/d Kitaabun Nikah

Praktik mengajar (Micro teaching) merupakan salah satu syarat yang harus dilakukan santri untuk dapat lulus dalam ujian akhir di Pondok Pesantren APIK Kesugihan. Dalam pelaksanaannya Microteaching atau latihan mengajar dilakukan 6 kali pertemuan, 1 minggu dua kali pelaksanaan di kelas 1 dan kelas 2. Pada kegiatan Microteaching ini terdapat dua pengawas yang bertugas menilai bagaimana cara menyampaikan materi apakah dia menguasai atau tidak dalam menyampaikan materi. Apakah peserta ujian mampu berinteraksi dengan santri di kelas tersebut dan lain sebagainya. Pelaksanaan Microteaching di Madrasah Diniyah APIK tahun 2021 pada tanggal 13 Februari sampai dengan 10 Maret 2021. Materi yang diajarkan atau diujikan hanya ilmu alat saja yaitu Ilmu Nahwu dan Shorof.

Evaluasi yang sudah berjalan di Pondok Pesantren APIK ada pengawas khusus ujian di Madrasah Diniyah APIK yaitu diambil dari dewan asatidz yang berasal dari keluarga ndalem atau santri yang sudah menjadi ustadz yang telah lulus ujian kelas 3, akan tetapi dewan asatidz yang sudah sepuh tidak ikut mengawasi jalannya Microteaching. Penetapan pengawas ujian di musyawarahkan sebelumnya oleh kepala MADIN dan dewan asatidz. Selain pengawasan pada ujian atau tes, pengawasan juga dilakukan dengan membuat absesni untuk mengetahui prosentase kehadiran santri dan membuat absensi yang ditandatangani oleh santri sebagai bukti bahwa santri tersebut telah mengikuti ujian (kegiatan evaluasi belajar). 
Tabel 2. Jadwal Kelompok Micro Teaching dan Pengawas

\begin{tabular}{|l|l|}
\hline \multicolumn{1}{|c|}{ Kelompok 1 } & \multicolumn{1}{c|}{ Kelompok 2 } \\
\hline Ronaqu Nida & Hijriyah Hutri Fifty Nine \\
\hline Hasanah & Mayla \\
\hline Afi & Loita \\
\hline Isna & Linda \\
\hline
\end{tabular}

Tabel 3. Pengawas Micro Teaching Tanggal 13 Februari 2021 - 10 Maret 2021

\begin{tabular}{|c|c|c|c|c|}
\hline No & Hari/Tanggal & Jam & Kelas I & Kelas II \\
\hline 1 & $\begin{array}{l}\text { Sabtu, } \\
13-02-2021\end{array}$ & $19.00-20.00$ & $\begin{array}{l}\text { 1. Mufidatun Nida } \\
\text { 2. Isnaeni } \\
\text { Fadilatus. S }\end{array}$ & $\begin{array}{l}\text { 1. Mamluatul } \\
\text { KB } 2 . \\
\text { Maelatul } \\
\text { Ulfatul }\end{array}$ \\
\hline 2 & $\begin{array}{l}\text { Rabu, } \\
17-02-2021\end{array}$ & $19.00-20.00$ & $\begin{array}{l}\text { 1. Nur laelatul. M } \\
\text { 2. Mamluatul KB }\end{array}$ & $\begin{array}{l}\text { 1. Mufidatun } \\
\text { Nida } \\
\text { 2. Istitho'atul } \\
\text { Kh }\end{array}$ \\
\hline 3 & $\begin{array}{l}\text { Sabtu, } \\
20-02-2021\end{array}$ & $19.00-20.00$ & $\begin{array}{l}\text { 1. Mufidatun Nida } \\
\text { 2. Maelatul } \\
\text { Ulfatul. kh }\end{array}$ & $\begin{array}{l}\text { 1. Isnaeni } \\
\text { Fadilatus } \\
\text { 2. Mamluatul } \\
\text { KB } \\
\end{array}$ \\
\hline 4 & $\begin{array}{l}\text { Rabu, } \\
24-02-2021\end{array}$ & $19.00-20.00$ & $\begin{array}{l}\text { 1. Maelatul } \\
\text { Ulfatul. kh } \\
\text { 2. Mamluatul KB }\end{array}$ & $\begin{array}{l}\text { 1. Mufidatun } \\
\text { Nida } \\
\text { 2. Nur laelatul. } \\
\text { M }\end{array}$ \\
\hline 5 & $\begin{array}{l}\text { Sabtu, } \\
27-02-2021\end{array}$ & $19.00-20.00$ & $\begin{array}{l}\text { 1. Mufidatun Nida } \\
\text { 2. Istitho'atul } \mathrm{Kh}\end{array}$ & $\begin{array}{l}\text { 1. Mufidatun } \\
\text { Nida } \\
\text { 2. Istitho'atul } \\
\text { Kh }\end{array}$ \\
\hline 6 & $\begin{array}{l}\text { Rabu, } \\
\text { 03-03-2021 }\end{array}$ & $19.00-20.00$ & $\begin{array}{l}\text { 1. Maelatul } \\
\text { Ulfatul kh } \\
\text { 2. Nur laelatul. M }\end{array}$ & $\begin{array}{l}\text { 1. Mufidatun } \\
\text { Nida } \\
\text { 2. Mamluatul } \\
\text { KB }\end{array}$ \\
\hline 7 & $\begin{array}{l}\text { Sabtu, } \\
\text { 06-03-2021 }\end{array}$ & $19.00-20.00$ & $\begin{array}{l}\text { 1. Mufidatun Nida } \\
\text { 2. Isnaeni } \\
\text { Fadilatus. S }\end{array}$ & $\begin{array}{l}\text { 1. Maelatul } \\
\text { Ulfatul } \\
\text { 2. Mamluatul } \\
\text { KB }\end{array}$ \\
\hline 8 & $\begin{array}{l}\text { Rabu, } \\
10-03-2021\end{array}$ & $19.00-20.00$ & $\begin{array}{l}\text { 1. Nur laelatul. M } \\
\text { 2. Mamluatul KB }\end{array}$ & $\begin{array}{l}\text { 1. Mufidatun } \\
\text { Nida } \\
\text { 2. Maelatul } \\
\text { Ulfatul }\end{array}$ \\
\hline
\end{tabular}

\section{KESIMPULAN}

Berdasarkan hasil penelitian dan pembahasan data, penulis memperoleh kesimpulan yang dapat diambil dari penelitian sebelumnya yaitu mengenai 
Manajemen Pembelajaran Nahwu Shorof di Pondok Pesantren APIK Kecamatan Kesugihan Kabupaten Cilacap yang di dalamnya membahas tentang perencanaan, pelaksanaan, evaluasi pembelajaran Nahwu Shorof maka dapat disimpulkan sebagai berikut :

\section{Perencanaan Pembelajaran Nahwu Shorof}

Perencanaan dalam manajemen pembelajaran kitab Nahwu Shorof di Pondok Pesantren APIK Kecamatan Kesugihan meliputi : Perencanaan atau langkah awal dari manajemen pembelajaran Nahwu Shorof di Pondok Pesantren APIK itu meliputi : kurikulum, (rapat kurikulum, pembuatan jadwal pembelajaran, membuat perencanaan pembelajaran dan sarana prasarana), materi pembelajaran yang digunakan, metode pengajaran yang digunakan, evaluasi hasil (hasil belajar) yang dibuat bersama-sama oleh para ustadz atau ustadzah sesuai mapel yang diampu dengan cara bermusyawarah.

\section{Pelaksanaan pembelajaran Nahwu Shorof}

Pelaksanaan proses pembelajaran di Madrasah Diniyah (Madin) dilakukan oleh para santri di Pondok Pesantren APIK Kesugihan dan dewan asatidz pada pukul 19.0021.00 yang dibagi menjadi 2 jam pelajaran yaitu pukul 19.00-20.00 dan 20.00-21.00 WIB. Kegiatan ini telah disesuaikan dengan jadwal kegiatan yang sebelumnya telah dirapatkan

\section{Evaluasi Pembelajaran Nahwu Shorof}

Hasil belajar yang ada di Pondok Pesantren APIK Kesugihan berdasarkan teori di bab yaitu berupa tes atau ujian yang dilaksanakan dua kali dalam satu tahun yaitu tes nisfusanah dan tes akhirussanah. Tes atau ujian ini meliputi ujian tertulis dan ujian praktik (praktik ibadah, ujian hafalan, ujian qiro'atul qur'an, ujian qiro'atul kutub) dan khusus bagi peserta didik atau santri kelas III akan diadakan praktik mengajar (micro teaching) dan ujian di akhir semester untuk mendapatkan ijazah. Adapaun syarat mengikuti ujian adalah setiap santri harus menguasai mata pelajaran Nahwu dan Shorof serta telah lulus praktik mengajar atau micro teaching. 


\section{DAFTAR PUSTAKA}

Halim, Suhartini, M. Choirul Arif, dan A. Sunarto AS, (2009), Manajemen Pesantren, Yogyakarta: Pustaka Pesantren.

Arief Subhan, (2012), Lembaga Pendidikan Islam Indonesia Abad ke-20: Pergumulan antara Modernisasi dan Identitas, Jakarta: Kencana.

Azyumazri Azra, (1999), Pendidikan Islam: Tradisi dan Modernisasi Menuju Milenium Baru, Jakarta: Logos Wacana Ilmu.

Azyumardi Azra, (2012), Pendidikan Islam: Tradisi dan Modernisasi di Tengah Tantangan Millenium III, Jakarta Kencana Prenada media Grup.

Chusnul Chotimah dan Muhammad Fathurrohman, (2014), Komplemen Manajemen Pendidikan Islam, Konsep Integratif Pelengkap Manajemen Pendidikan Islam. Yogyakarta: Teras.

Fathul Aminudin Aziz, (2014), Manajemen Pesantren, Purwokerto: STAIN Press. Hartono, (2011), Pendidikan Integratif, Purwokerto: STAIN Press.

Imam Tokhah dan Barizi, (2004), Membuka Jendela Pendidikan: Mengurai Akar Tradisi, Jakarta: PT. Raja Grafindo Persada.

Kementerian Agama RI, (2012), Panduan Integrasi Kultur Kepesantrenan ke dalam Manajemen Sekolah, Jakarta: Kemenag RI.

Khalilulloh, (tt), Media Pembelajaran Bahasa Arab, Yogyakarta: Aswaja Pressindo. Manfredziemek, (1986), Pesantrendalam Perubahan Sosial, Jakarta: P3M.

Marno dan Triyo Supriyatno, (2003), Manajemen dan Kepemimpinan Pendidikan Islam,

Bandung: PT. Refika Aditama.

Muhammad Hambal Shafwan, (2014), Inti Sari Sejarah Pendidikan Islam, Solo: Putaka Arafah.

Nana Sudjana. (2011). Penilaian Hasil dan Proses Belajar Mengajar. Bandung: Rosda Karya.

Nurcholis Madjid, (1997), Bilik-bilik Pesantren, Jakarta: Paramadina.

Ridwan Natsir, (2005), Mencari Tipologi Format Pendidikan Ideal: Pondok Pesantren di Tengah Arus Perubahan, Yogyakarta: Pustaka Pelajar.

Rusman, (2019), Manajemen Kurikulum, Jakarta: PT. Raja Grafindo Persada.

Rustam Ibrahim, (2005), Bertahan di Tengah Perubahan: Pesantren Salaf, Kiai dan Kitab Kuning, Jogjakarta: Sibuku.

Sumarso Mestoko, (1986), Pendidikan di Indonesia dari jaman ke jaman, Jakarta: Balai Pustaka. 
Sulistyorini, (2009), Manajemen Pendidikan Islam, Konsep, Strategi dan aplikasi.

Yogyakarta: Teras.

Wahjoetomo, (1997), PerguruanTinggiPesantren, Jakarta: Gema Insani Press.Wina Sanjaya. (2016). Strategi Pembelajaran Berorientasi Standar Proses Pendidikan.

Jakarta: Prenadamedia Group.

Zamakhsyari Dhofier, (2011), Tradisi Pesantren: Studi tentang Pandangan Hidup Kyai.

Jakarta: LP3ES. 